\title{
Alien flora of Turkey: checklist, taxonomic composition and ecological attributes
}

\author{
Ahmet Uludağ ${ }^{1,2}$, Necmi Aksoy³, Ayşe Yazlık²,4, Zübeyde Filiz Arslan², \\ Efecan Yazmış', İlhan Üremişs ${ }^{5}$, Tiziana Antonella Cossu ${ }^{6,7}$, Quentin Groom ${ }^{8}$, \\ Jan Pergl ${ }^{4}$, Petr Pyšek ${ }^{4,9}$, Giuseppe Brundu ${ }^{6}$
}

I Faculty of Agriculture, Çanakkale Onsekiz Mart University, Çanakkale, Turkey 2 Faculty of Agriculture and Nature Sciences, Düzce University, Düzce, Turkey 3 Faculty of Forestry, Düzce University, Düzce, Turkey 4 Institute of Botany, Department of Invasion Ecology, The Czech Academy of Sciences, CZ-25243 Pruhhonice, Czech Republic 5 Faculty of Agriculture, Mustafa Kemal University, Hatay, Turkey 6 University of Sassari, Department of Agriculture, Viale Italia 39, 07100 Sassari, Italy 7 Department of Collections, Royal Botanic Gardens, Kew, UK 8 Botanic Garden Meise, 1860 Meise, Belgium 9 Department of Ecology, Faculty of Science, Charles University, Viničná 7, CZ-128 44 Prague, Czech Republic

Corresponding author: Giuseppe Brundu (gbrundu@tin.it)

Academic editor: I. Kühn | Received 28 February 2017 | Accepted 24 April 2017 | Published 2 June 2017

Citation: Uludağ A, Aksoy N, Yazlık A, Arslan ZF, Yazmış E, Üremiş I, Cossu TA, Groom Q, Pergl J, Pyšek P, Brundu G (2017) Alien flora of Turkey: checklist, taxonomic composition and ecological attributes. NeoBiota 35: 61-85. https:// doi.org/10.3897/neobiota.35.12460

\begin{abstract}
The paper provides an updated checklist of the alien flora of Turkey with information on its structure. The alien flora of Turkey comprises 340 taxa, among which there are 321 angiosperms, 17 gymnosperms and two ferns. Of the total number of taxa, $228(68 \%)$ are naturalized and $112(32 \%)$ are casual. There are 275 neophytes (172 naturalized and 103 casual) and 61 archaeophytes (52 naturalized and 9 casual); four species could not be classified with respect to the residence time. In addition, 47 frequently planted taxa with a potential to escape are also listed. The richest families are Asteraceae (38 taxa), Poaceae (30), Fabaceae (23) and Solanaceae (22). As for the naturalized alien plants, the highest species richness is found in Asteraceae (31 taxa), Poaceae (22), Amaranthaceae (18) and Solanaceae (15). The majority of alien taxa are perennial (63.8\% of the total number of taxa with this life history assigned, including those with multiple life histories), annuals contribute $33.8 \%$ and $2.4 \%$ are biennial aliens. Among perennials the most common life forms are phanerophytes, of which $20.3 \%$ are trees and $12.6 \%$ shrubs; woody vines, stem succulents, and aquatic plants are comparatively less represented. Most of the 340 alien taxa introduced to Turkey have their native ranges in Americas (44.7\%) and Asia (27.6\%). Of other regions, 9.1\% originated in Africa, $4.4 \%$ in Eurasia, 3.8\% in Australia and Oceania and 3.5\% in the Mediterranean. The majority of taxa $(71.9 \%)$ were introduced intentionally, whereas the remaining $(28.1 \%)$ were introduced
\end{abstract}

Copyright Ahmet Uludağ et al. This is an open access article distributed under the terms of the Creative Commons Attribution License (CC BY 4.0), which permits unrestricted use, distribution, and reproduction in any medium, provided the original author and source are credited. 
accidentally. Among the taxa introduced intentionally, the vast majority are ornamental plants (55.2\%), $10.0 \%$ taxa were introduced for forestry and $6.7 \%$ as crops. Casual alien plants are most commonly found in urban and ruderal habitats $(40.1 \%)$ where naturalized taxa are also often recorded $(27.3 \%)$. Plants that occur as agricultural weeds are typically naturalized rather than casual (16.0\% vs $7.1 \%$, respectively). However, (semi)natural habitats in Turkey are often invaded by alien taxa, especially by those that are able to naturalize.

\section{Keywords}

Alien flora, Turkey, casual and naturalized alien plants

\section{Introduction}

Turkey has a long tradition of floristic research and as a result its native flora is satisfactorily investigated. With more than 12,000 plant taxa (Davis 1965-1985, Davis et al. 1988, Güner et al. 2000, 2012) and new species being continuously described, including new endemics (Güner et al. 2012, Özhatay et al. 2013, 2015), the flora of Turkey is the richest among the Mediterranean, European and neighbouring countries (Ekim and Güner 1986). The majority of this total number is represented by native taxa with $31 \%$ of endemics (Güner et al. 2012). Turkey's landscape and ecological diversity has contributed not only to a high floristic richness, but has also allowed for successful introductions and cultivation of a great number of crops, fruit species (Ercisli 2004) and forest trees (Atalay et al. 2014).

On the contrary, up to now there was only limited information on Turkish alien flora. Being located at the crossroads of three continents, there has always been an intense movement of humans and goods across Turkey over the history due to human migration, and in modern Turkey both plants and animals were being introduced intentionally and unintentionally in great quantities. Suitable conditions for the cultivation and use and subsequent naturalization of plants introduced into the country are supported historically. Turkey is a country of special significance in the history of agriculture, with some of the earliest sites of plant domestication nearly 10,000 years ago (Aksoy and Oksar 2015), and today $50 \%$ of the country area is agricultural land (FAO 2017).

With this background, it is somewhat surprising that so far, the main source of information about alien flora of Turkey was a checklist generated for the DAISIE project (Delivering Alien Invasive Species Inventories for Europe, 2004-2008; see DAISIE 2008, Lambdon et al. 2008), based on the several decades old flora (Davis 1965-1985) that was rather outdated in terms of inventory of alien species. Therefore, the DAISIE project reported only 220 alien taxa for Turkey, of which only 95 were assigned the naturalization status with certainty (Lambdon et al. 2008), which is an underestimation of the real situation. In fact, it should be taken into account that DAISIE included mainly the European part of Turkey, which represents only 3\% of the Turkish territory. More recently, new insights into this aspect were provided by the book "Türkiye İstilâcı Bitkiler Kataloğu" (Catalogue of the invasive plants of Turkey) by Önen (2015). 
However, such lack of a recent account on the alien flora represents a serious constraint to the management of those plants that are currently invasive or may become so in the future. As generally agreed, alien species lists form the basis for much of the current research on biological invasions, for guiding legislation and code of conducts, as input to decision making and risk assessment and in the formulation of management policies and strategies for nature conservation (Hoffmann and Broadhurst 2016, Woodford et al. 2016, Jacobs et al. 2017). From the scientific point of view, macroecological analyses of alien floras has received much attention recently and improved the understanding of historical flows of alien species among continents (van Kleunen et al. 2015), the dynamics of their accumulation (Seebens et al. 2017) as well as factors driving the variation in regional diversity of alien floras (Pyšek et al. 2009, 2010, 2015, Essl et al. 2011, Seebens et al. 2015).

The aim of this paper is therefore to fill the important gap in the knowledge on alien flora in one of the richest in species countries in Eurasia, by compiling the first comprehensive list of alien plants in Turkey and providing an analysis of its taxonomic composition, origin and ecological structure.

\section{Methods}

\section{Study area}

Turkey is a large and diverse country located between $25^{\circ} 40^{\prime}$ to $44^{\circ} 48^{\prime} \mathrm{E}$, and $35^{\circ} 51^{\prime}$ to $42^{\circ} 06^{\prime} \mathrm{N}$. The total area is $814,578 \mathrm{~km}^{2}$ of which $97 \%$ is located in Asia and $3 \%$ in in Europe. It is divided into seven geographical regions: Black Sea, Eastern Anatolia, South Eastern Anatolia, Mediterranean, Aegean, Marmara and Inner Anatolia. The average altitude is $1,141 \mathrm{~m}$ a.s.l., and it increases from West to East; $18 \%$ of Turkey is below $500 \mathrm{~m}$ and $25 \%$ between 500 and $1,000 \mathrm{~m}$. Plains up to 2,000 $\mathrm{m}$ of altitude and high plateaus up to 2,500 m are another source of biodiversity of native plants while providing potential diverse niches for the naturalization of alien species. Turkey's natural environment is very diverse in terms of climate, ranging from subtropical to cold temperate, as well as topography and geology (Atalay 2002, 2010, 2011), supporting a variety of vegetation types (Akman and Ketenoğlu 1986). Annual precipitation varies from 300 to $2,000 \mathrm{~mm}$, and mean annual temperature from 4 to $19^{\circ} \mathrm{C}$. Some areas are prone to frosts for almost 10 months, while some have frost for only one day in a year. The growing period varies from almost the whole year to less than 140 growing days. Turkey is surrounded by an $8,333 \mathrm{~km}$ coastline with Black Sea at the North, Marmara Sea between two peninsulas, and Aegean Sea at West and Mediterranean at South. The coastal areas represent a dynamic, ecologically fragile environment with threatened habitats in which a diverse range of human activities are carried out (Acar et al. 2014). In addition, the majority of Turkey's ever-increasing population resides in coastal areas (Erginöz and Doğan 1997). Among cities that represent important points of entry of alien species into the country, İstanbul with a population of almost 15 million is Turkey's most populated metropolitan area and the economic powerhouse of the country. Its geographical 
characteristics and topography allow for the existence of diverse microclimatic zones to exist in a relatively small area of $5,461 \mathrm{~km}^{2}$ (Güneralp et al. 2013). The 2,875-km long border of Turkey with its neighbours Georgia, Armenia, Azerbaijan, Iran, Iraq, Syria, Greece and Bulgaria is associated with a high probability of entry and occurrence of alien plant species in habitats along adjacent roadside corridors that represent an important pathway for alien plants (Wilson et al. 2016).

\section{Data sources used to compile the inventory}

The first flora dedicated to Turkey is composed of the five volumes of Boissier's Flora Orientalis (Boissier 1867-1884) and its supplement (Boissier 1888) where alien species are occasionally reported. However, the basic data source used for the present inventory is the Flora of Turkey and the East Aegean Islands (Davis 1965-1985, Davis et al. 1988, Güner et al. 2000, 2012). This source has been complemented with information extracted from all the available literature, such as, in particular, the papers published after 2000 in the Turkish Journal of Botany and elsewhere. In addition, dedicated studies (Uremis et al. 2014, Arslan et al. 2015) and field surveys (e.g. Brundu et al. 2011) were taken into account as well as herbarium samples stored at the Düzce University Forestry Faculty Herbarium (DUOF) and other herbaria in Turkey (GAZİ, ISTO, AİBO and ISTE). We also screened the GBIF database, which holds 265,818 plant records for Turkey (GBIF 2017); however, alien plant species are significantly underrepresented in this source. We also used information from an ongoing project dedicated to the online flora of Turkey (Tübives - http://www.tubives.com/index.php) (Bakis et al. 2011), an initiative for a new Flora of Turkey with illustrations 'Resimli Türkiye Florası Volume 1 (Güner 2014), and 'Bizim Bitkiler' (http://www.bizimbitkiler.org. tr/v2/index.php), another online flora of Turkey which includes the last checklist of vascular flora of Turkey by Güner et al. (2012).

\section{Classification of taxa and their characteristics}

This inventory focuses on plant species alien to Turkey (synonyms: exotic, introduced, nonindigenous, non-native), i.e. species present in the country because human actions enabled them to overcome fundamental biogeographical barriers (Richardson et al. 2000, Blackburn et al. 2011); they occur in Turkey as a result of intentional or accidental introduction by humans, or as a result of natural spread from other regions where they were introduced by humans. Crosses resulting from hybridization with one or both alien species involved are also considered alien (Pyšek et al. 2004). In addition, we included in this inventory some taxa that are native to a part of the country but introduced elsewhere in Turkey, i.e. alien in Turkey, following an approach proposed by Lambdon et al. (2008) for Europe. 
We classified alien plant species according to the stage they reached along the introduction-naturalization-invasion continuum (Richardson and Pyšek 2006, Richardson et al. 2000, 2011, Blackburn et al. 2011). However, due to a lack of data on the rate of spread we did not classify species as invasive and only classified them in two main categories, casual or naturalized. The complete inventory (Suppl. material 1: Table 1) lists also additional species that are presently recorded only in cultivation outside urban areas, but over very large areas, such as tree species in planted forests, and that could start to naturalize in the future due to potentially strong propagule pressure or climate change. These species are, however, not taken into account for data analyses. Taxa were further classified with respect to their residence time, i.e. separated into archaeophytes and neophytes (see e.g. Pyšek et al. 2004, 2012 for delimitation). Affiliation of taxa to families follows the approach of the Angiosperm Phylogeny Group (Stevens 2001 onwards, APG IV 2016). Plant names have been verified using IPNI (International Plant Name Index, http://www.ipni.org/), The Plant List (2010, version 1, published on the Internet; http://www.theplantlist.org/), WCSP and the African Plants Database (APD, version 3.4.0), updated by the Conservatoire et Jardin botaniques de la Ville de Genève and the South African National Biodiversity Institute, Pretoria, South Africa (http://www.ville-ge.ch/musinfo/bd/cjb/africa). We followed, to our best attempt, the accepted and correct nomenclature according to current taxonomic standards.

Information on life history, region of origin, pathway of introduction (intentional vs accidental) and habitat affiliation was extracted from literature and from the above cited sources for each species.

Life forms were classified as follows: therophytes, hydrophytes, chamaephytes, geophytes, hemicryptophytes and phanerophytes (Raunkiaer 1934, 1937). In addition, growth form and life history were assigned according to the Thesaurus of Plant Characteristics for Ecology and Evolution (Garnier et al. 2017) and other specific literature (Pérez-Harguindeguy et al. 2016). Growth-forms reported for aquatic plants follow Brundu (2015).

The checklist has been archived on the Global Biodiversity Information Facility (Uludag et al. 2017).

\section{Statistical analysis}

Differences in representation of life forms within casual and naturalized species were tested by contingency tables with control for overdispersion (if needed using quasiPoisson distribution) (Crawley 2007). To test individual differences among life forms and species groups, adjusted standardized residuals of G-tests were compared with critical values of a normal distribution (Řehák and Řeháková 1986). All analyses were performed in R 3.0.2 (R Core Team 2015). 


\section{Results}

\section{Species numbers and taxonomic composition}

The alien flora of Turkey comprises 340 taxa, among which there are 321 angiosperms, 17 gymnosperms and two ferns. Of the total number of taxa, 228 (67.1\%) are naturalized and $112(32.9 \%)$ are casual (Appendix 1; for the complete list of taxa, which includes additional 47 frequently planted taxa noted above, see Suppl. material 1). Related to the total plant diversity of $-12,000$ species in the Turkish flora, the contribution of alien taxa is $-2.8 \%$ and that of naturalized taxa $-1.9 \%$. Of the taxa for which the classification according to residence time was possible, there are 275 neophytes (172 naturalized and 103 casual) and 61 archaeophytes (52 naturalized and 9 casual).

Turkey's alien flora includes representatives of 92 families and 251 genera. There are seven families with at least 10 aliens that together comprise $44.7 \%$ of the total alien taxa richness of the country; the richest are Asteraceae (38 taxa, corresponding to $11.2 \%$ of all aliens), Poaceae (30, 8.8\%), Fabaceae (23, 6.8\%) and Solanaceae (22, 6.5\%). As for the naturalized alien plants, the highest species richness is found in Asteraceae (31 taxa, $13.6 \%$ of the total number of naturalized aliens), Poaceae (22, 9.6\%), Amaranthaceae $(18,7.9 \%)$ and Solanaceae. Over a half of the naturalized alien richness $(51.8 \%)$ is concentrated in eight families that contain more than four naturalized taxa (Table 1).

The most represented genus is Amaranthus with 13 taxa that are all naturalized, contributing thus $3.3 \%$ and $5.7 \%$ to all aliens and naturalized aliens, respectively. Solanum is also rather rich in aliens, but of the 11 taxa only five are naturalized. Other genera, that are represented by more than five species and the naturalization success of their representatives is high, are Euphorbia (88.9\% of all aliens in the genus are naturalized), Acacia (83.3\%) and Oxalis (100\%). The 11 genera with at least four alien taxa in Turkey together account for $17.6 \%$ of the total alien plant richness and $26.3 \%$ of the naturalized richness of the country (Table 2).

\section{Ecological attributes}

The majority of alien taxa are perennial $(63.8 \%$ of the total number of taxa with this life history assigned, including those with multiple life histories), annuals are also greatly represented $(33.8 \%)$ and only $2.4 \%$ are biennials. Among perennials the most common life forms are phanerophytes, i.e. trees (20.3\%) and shrubs (12.6\%); woody vines, stem succulent, bambusoid and aquatic plants are comparatively less represented. There were significant differences in the counts per life history between casuals and naturalized species $\left(\chi^{2}=29.85, \mathrm{DF}=0,6, \mathrm{p}<0.001\right)$. This significant difference was due to annuals (therophytes) where the observed counts were higher than expected by chance for naturalized species and lower for casuals and due to woody species (phanerophytes) where the situation was reversed (Figure 1). 
Table I. The most represented families in the alien flora of Turkey, ranked according to the total number of alien taxa, with their representatives classified according to their status. For each family, the number of casual and naturalized taxa and the percentage of naturalized among total aliens are provided. Family names follow APG classification (Stevens 2001 onwards, APG IV 2016).

\begin{tabular}{l|c|c|c|c}
\hline \multicolumn{1}{c|}{ Family } & $\begin{array}{c}\text { Total no. of alien } \\
\text { taxa }\end{array}$ & No. of casual taxa & $\begin{array}{c}\text { No. of naturalized } \\
\text { taxa }\end{array}$ & $\begin{array}{c}\text { \% of naturalized } \\
\text { taxa }\end{array}$ \\
\hline Asteraceae & 38 & 7 & 31 & 81.6 \\
\hline Poaceae & 30 & 8 & 22 & 73.3 \\
\hline Fabaceae & 23 & 11 & 12 & 52.2 \\
\hline Solanaceae & 22 & 7 & 15 & 68.2 \\
\hline Amaranthaceae & 18 & 0 & 18 & 100.0 \\
\hline Euphorbiaceae & 11 & 1 & 10 & 90.9 \\
\hline Rosaceae & 10 & 6 & 4 & 40.0 \\
\hline Cupressaceae & 9 & 3 & 6 & 66.7 \\
\hline Pinaceae & 8 & 4 & 4 & 50.0 \\
\hline Oxalidaceae & 7 & 0 & 7 & 100.0 \\
\hline Sapindaceae & 7 & 2 & 5 & 71.4 \\
\hline Convolvulaceae & 6 & 2 & 4 & 66.7 \\
\hline Aizoaceae & 5 & 0 & 5 & 100.0 \\
\hline Apocynaceae & 5 & 2 & 3 & 60.0 \\
\hline Moraceae & 5 & 3 & 2 & 40.0 \\
\hline
\end{tabular}

Table 2. The most represented genera in the alien flora of Turkey, classified according to their status. For each genus, number of casual and naturalized taxa and percentage of naturalized among total aliens in the genus are provided. Genera are ranked according the total number of alien taxa.

\begin{tabular}{l|c|c|c|c}
\hline \multicolumn{1}{c|}{ Genus } & $\begin{array}{c}\text { Total no. of alien } \\
\text { taxa }\end{array}$ & No. of casual taxa & $\begin{array}{c}\text { No. of naturalized } \\
\text { taxa }\end{array}$ & $\begin{array}{c}\% \text { of naturalized } \\
\text { taxa }\end{array}$ \\
\hline Amaranthus & 13 & 0 & 13 & 100.0 \\
\hline Solanum & 11 & 6 & 5 & 45.5 \\
\hline Euphorbia & 9 & 1 & 8 & 88.9 \\
\hline Oxalis & 7 & 0 & 7 & 100.0 \\
\hline Acacia & 6 & 1 & 5 & 83.3 \\
\hline Acer & 4 & 1 & 3 & 75.0 \\
\hline Bidens & 4 & 0 & 4 & 100.0 \\
\hline Cotoneaster & 4 & 1 & 3 & 75.0 \\
\hline Erigeron & 4 & 0 & 4 & 100.0 \\
\hline Ipomoea & 4 & 0 & 4 & 100.0 \\
\hline Paulownia & 4 & 4 & 0 & 0.0 \\
\hline Physalis & 4 & 0 & 4 & 100.0 \\
\hline
\end{tabular}




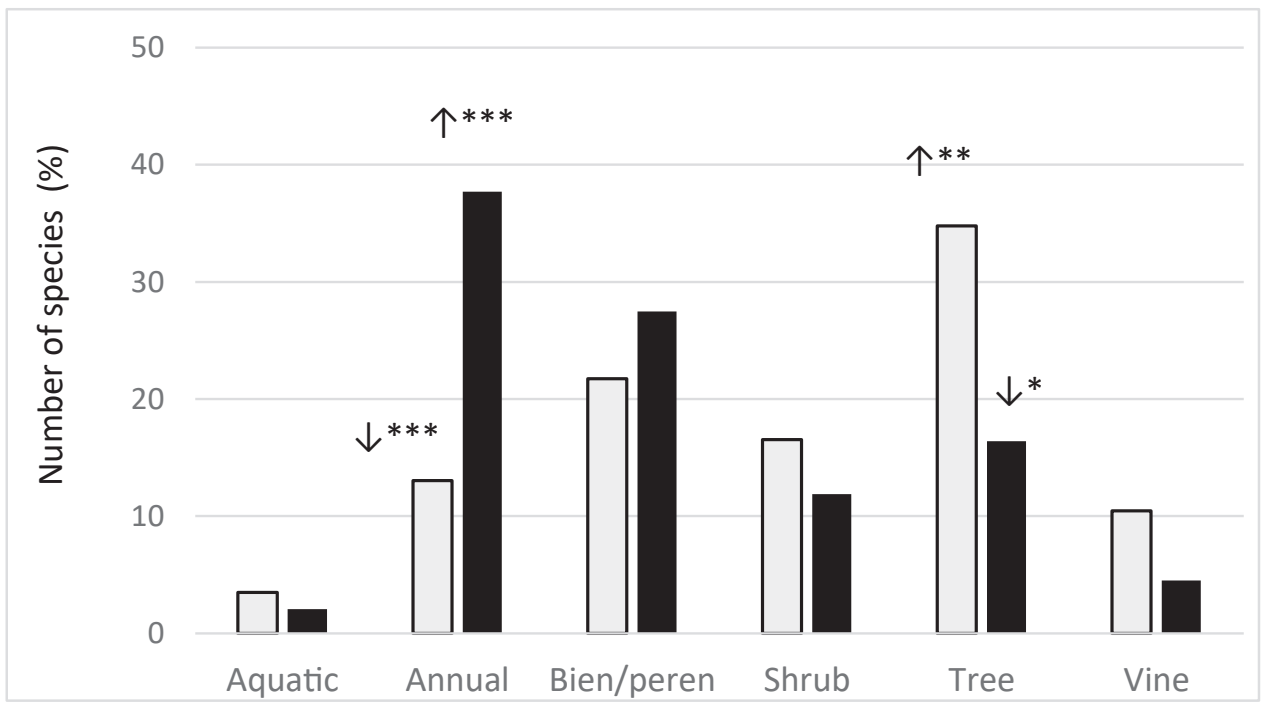

Figure I. Frequency of alien species in the flora of Turkey categorized according to their Raunkiaer's life forms, shown separately for casuals (white bars, $n=112$ ) and naturalized taxa (black bars, $n=228$ ). Bars indicate the percentage contribution of each life form to the total numbers of incidences within casual and naturalized. Significant differences and their directions are indicated above bars $\left(.<0.1,{ }^{*}<0.05,{ }^{* *}\right.$ $\left.<0.01,{ }^{* * *}<0.001\right)$.

Table 3. Structure of the alien flora of Turkey according to origin and number of casual and naturalized species, with percentages of naturalized taxa among total aliens.

\begin{tabular}{l|c|c|c|c}
\hline Native range & $\begin{array}{c}\text { Total no. of alien } \\
\text { taxa }\end{array}$ & No. of casual taxa & $\begin{array}{c}\text { No. of naturalized } \\
\text { taxa }\end{array}$ & $\begin{array}{c}\text { \% of naturalized } \\
\text { taxa }\end{array}$ \\
\hline America & 152 & 48 & 104 & 30.6 \\
\hline Asia & 94 & 33 & 61 & 17.9 \\
\hline Africa & 31 & 13 & 18 & 5.3 \\
\hline Eurasia & 15 & 2 & 13 & 3.8 \\
\hline $\begin{array}{l}\text { Australia \& } \\
\text { Oceania }\end{array}$ & 13 & 8 & 5 & 1.5 \\
\hline Mediterranean & 12 & 1 & 11 & 3.2 \\
\hline Europe & 9 & 1 & 8 & 2.4 \\
\hline $\begin{array}{l}\text { Garden origin } \\
\text { \& hybrids }\end{array}$ & 8 & 5 & 3 & 0.9 \\
\hline $\begin{array}{l}\text { Other \& } \\
\text { unknown }\end{array}$ & 6 & 1 & 5 & 1.5 \\
\hline
\end{tabular}

Most of the 340 alien taxa introduced to Turkey have their native ranges in Americas $(44.7 \%)$ and Asia (27.6\%). Of other regions, 9.1\% originated in Africa, $4.4 \%$ in Eurasia, 3.8\% in Australia and Oceania, and 3.5\% in the Mediterranean (see Table 3 for species numbers with respect to the area of origin).

The majority of taxa in the Turkish alien flora (71.9\%) were introduced intentionally, whereas the remaining $(28.1 \%)$ were introduced accidentally. Among the taxa 
Table 4. Habitats in which the alien plant taxa are found in Turkey, shown separately for casual and naturalized taxa, with percentages of the total shown for each category. Natural/semi-natural habitats include the categories of the CORINE Land cover class 3 (Forest and semi-natural areas).

\begin{tabular}{l|c|c|c|c}
\hline \multicolumn{1}{c|}{ Habitat } & Casual alien & \% & Naturalized alien & \% \\
\hline Natural/semi-natural habitats & 56 & 28.4 & 145 & 28.3 \\
\hline Urban/ruderal habitats & 79 & 40.1 & 140 & 27.3 \\
\hline Coastal habitats & 34 & 17.3 & 96 & 18.7 \\
\hline Agricultural land & 14 & 7.1 & 82 & 16.0 \\
\hline Riparian habitats/wetlands/lakes & 14 & 7.1 & 50 & 9.7 \\
\hline
\end{tabular}

introduced intentionally, the vast majority are ornamental plants (55.2\%), 10.0\% taxa were introduced for forestry (planted forest, reforestation, sand dune stabilization or soil protection) and $6.7 \%$ as crops (i.e. plant taxa cultivated for the production of food, forage, fruit, fibre, dye or drugs).

Casual alien plants are most commonly found in urban and ruderal habitats $(40.1 \%$ of their total number) where naturalized taxa are also often recorded (27.3\%). Plants that occur as agricultural weeds are typically naturalized rather than casual $(16.0 \%$ vs $7.1 \%$, respectively. However, (semi)natural habitats in Turkey are often invaded by alien taxa, especially by those that are able to naturalize (Table 4).

\section{Discussion and conclusions}

This is the first comprehensive compilation and analysis of all available records on alien plant taxa in Turkey. It provides the first assessment of their status, introduction purposes and main types of invaded habitats. It also pinpoints knowledge gaps in the geographic and biogeographic distribution and the quantification of environmental and economic impacts.

The total number of the alien taxa reported for Turkey here (340) is relatively low compared to other Mediterranean and Southern European countries, namely France (1,258 taxa), Italy (1,023), Spain (933) and Portugal (547) (Lambdon et al. 2008, Celesti-Grapow et al. 2009) and numerically comparable with Greece (343; Arianoutsou et al. 2010, Dimopoulos et al. 2016). The same is true for the naturalized species richness in Turkey (228 taxa), for which higher numbers are reported for e.g. France (732), Spain (495) or Italy (440), but comparable numbers for Portugal (261) and lower for Greece (134) (Lambdon et al. 2008). This fact, together with the remarkably high richness of native flora of Turkey, makes the contribution of alien species to the total plant diversity of the country relatively low, with the values between 1.9 and $2.8 \%$ being by an order of magnitude lower than in some other European countries (e.g. Pyšek et al. 2012) or this continent as a whole. Europe, with a comparable native plant diversity as Turkey, $-10,000$ native species (Winter et al. 2009), harbours 1,780 naturalized aliens from overseas and if one considers also intracontinental aliens 
the number reaches 3,749 taxa (Lambdon et al. 2008) or 4,140 according to the most recent account in GloNAF database (van Kleunen et al. 2015).

This is the first comprehensive catalogue for Turkey and it is based mainly on literature and herbarium data, with only a limited number of dedicated field surveys. Other Mediterranean countries such as France, Italy or Spain have a longer tradition of floristic research on alien plants, whose appearance and establishment have long been documented by botanists there (e.g., by Saccardo 1909). It is therefore possible that casual species are underestimated in the dataset, as casuals in general, and escaped ornamentals in particular (Pergl et al. 2016b), are rarely recorded in botanical works nor are they often collected in herbaria. Another possible explanation for the lower number of alien plants than in some other European countries is that although cultivation of ornamental plants dates back to ancient times, there has been rapid development and change in the ornamental plants sector in Turkey only after the 1980s and this development has gained speed only in the 2000s (Çelik and Arisoy 2013).

The rate of naturalization (proportion of naturalized to all aliens) is $67 \%$ in Turkey, i.e. the same as in Cyprus but higher than in Greece (41\%), Spain (53\%), Portugal (47\%) and Italy (51\%) (Arianoutsou et al. 2010). On the contrary, with the exception of Bulgaria, there is only very limited knowledge on the alien flora of Georgia, Armenia, Azerbaijan, Iran, Iraq, Syria which impedes comparisons between these countries and, at the same time, forecasting of future trends for the entire Mediterranean region.

National inventories of alien plants are one of the key components for evaluating the status of biodiversity in a given country, as well as threats to endangered species, and provide source data for creating relevant indicators (Lambdon et al. 2008, CelestiGrapow et al. 2010, Pyšek et al. 2012, van Kleunen et al. 2015, Latombe et al. 2017). Such data are needed for early warning systems, prioritization of management and implementation of effective policy measures (Brunel et al. 2010). The publication of checklists also helps neighbouring countries and trading partners to assess the threat from potential invasions of new species to arrive and checklists can contribute to socalled horizon scanning exercises looking for potential new threats (Roy et al. 2014, Latombe et al. 2017).

Identifying those species that represent potential or future threats, while still at an early stage of invasion, represents a major challenge for prediction (Lambdon et al. 2008, Brunel et al. 2010). Detailed knowledge of the pool of alien naturalized species from which emerging invaders recruit can provide national authorities in Turkey with an instrument for prioritization of management measures and allocation of resources to those species where future spread, and environmental and socioeconomic impacts are likely to occur (Brunel et al. 2010, Pergl et al. 2016a, Rumlerová et al. 2016). The results of the present research will increase the awareness of alien plant taxa in Turkey and neighbouring countries and trigger further dedicated specialized studies, such as assessment of the impact by using standard scoring systems (e.g. Blackburn et al. 2014, Nentwig et al. 2016). New alien species are bound to arrive and spread in Turkey and we hope that publication of this list will encourage further recording so that the impacts of these species can be minimized. 


\section{Acknowledgments}

PP and JP were supported by long-term research development project RVO 67985939 and Premium Academiae award to PP from The Czech Academy of Sciences. The authors also acknowledge support from the COST Action TD1209 "Alien Challenge" and FA1203 "SMARTER". AU and NA have been supported partly by the ESENIASTOOLS project which is funded by the Financial Mechanism of the European Economic Area (2009-2014). We gratefully acknowledge G. Domina and two anonymous reviewers whose comments and suggestions greatly helped to improve the present research.

\section{References}

Acar C, Seyran HK, Uzun P (2014) The analysis and assessment of the vegetation on coastal revetments: the case of Trabzon (Turkey). Rendiconti Lincei, Scienze Fisiche e Naturali 25: 141-153. https://doi.org/10.1007/s12210-014-0301-5

Akman Y, Ketenoğlu O (1986) The climate and vegetation of Turkey. Proceedings of the Royal Society of Edinburgh, Section B: Biological Sciences 89: 123-134. https://doi. org/10.1017/S0269727000008964

Aksoy U, Oksar RE (2015) An overview of horticulture in Turkey. Chronica Horticulturae 55: 17-22.

APG IV (2016) An update of the Angiosperm Phylogeny Group classification for the orders and families of flowering plants: APG IV. Botanical Journal of the Linnean Society 181: 1-20. https://doi.org/10.1111/boj.12385

Arianoutsou M, Bazos I, Delipetrou P, Kokkoris Y (2010) The alien flora of Greece: taxonomy, life traits and habitat preferences. Biological Invasions 12: 3525-3549. https://doi. org/10.1007/s10530-010-9749-0

Arslan ZF, Uludag A, Uremis I (2015) Status of invasive alien plants included in EPPO Lists in Turkey. EPPO Bulletin 45: 66-72. https://doi.org/10.1111/epp.12176

Atalay I, Efe R, Öztürk M (2014) Ecology and classification of forests in Turkey. Procedia - Social and Behavioral Sciences 120: 788-805. https://doi.org/10.1016/j.sbspro.2014.02.163

Atalay I (2002) Ecoregions of Turkey. Publ. no. 163. The Ministry of Environment and Forestry Press, Ankara.

Atalay I (2010) Applied climatology. Meta Press, Izmir.

Atalay I (2011) Soil formation, classification and geography. Ed 4. Meta Press, Izmir.

Bakiş Y, Babaç MT, Uslu E (2011) Updates and improvements of Turkish Plants Data Service (TÜBIVES). In: 6th International Symposium on Health Informatics and Bioinformatics (HIBIT), IEEE, 136-140. https://doi.org/10.1109/HIBIT.2011.6450823

Blackburn TM, Essl F, Evans T, Hulme PE, Jeschke JM, Kühn I, Kumschick S, Marková Z, Mrugała A, Nentwig W, Pergl J, Pyšek P, Rabitsch W, Ricciardi A, Richardson DM, Sendek A, Vilà M, Wilson JRU, Winter M, Genovesi P, Bacher S (2014) A unified classification of alien species based on the magnitude of their environmental impacts. PLoS Biology 12: e1001850. https://doi.org/10.1371/journal.pbio.1001850 
Blackburn TM, Pyšek P, Bacher S, Carlton JT, Duncan RP, Jarošík V, Wilson JRU, Richardson DM (2011) A proposed unified framework for biological invasions. Trends in Ecology and Evolution 26: 333-339. https://doi.org/10.1016/j.tree.2011.03.023

Boissier E (1867-1884) Flora Orientalis, sive enumeratio plantarum in Oriente a Graecie et Aegypto ad Indiae fines hucusque observaturum, Vol. 1-5. H. Georg, Bibliopolam, Genevae et Basileae.

Boissier E (1888) Flora Orientalis, sive enumeratio plantarum in Oriente a Graecie et Aegypto ad Indiae fines hucusque observaturum. Supplementum (Ed. R. Buser). H. Georg, Bibliopolam, Genevae et Basileae.

Brundu G, Aksoy N, Brunel S, Eliáš P, Fried G (2011) Rapid surveys for inventorying alien plants in the Black Sea region of Turkey. EPPO Bulletin 41: 208-216. https://doi. org/10.1111/j.1365-2338.2011.02455.x

Brundu G (2015) Plant invaders in European and Mediterranean inland waters: profiles, distribution, and threats. Hydrobiologia 746: 61-79. https://doi.org/10.1007/s10750-0141910-9

Brunel S, Schrader G, Brundu G, Fried G (2010) Emerging invasive alien plants for the Mediterranean Basin. EPPO Bulletin 40: 219-238. https://doi.org/10.1111/j.13652338.2010.02378.x

Celesti-Grapow L, Alessandrini A, Arrigoni PV, Banfi E, Bernardo L, Bovio M, Brundu G, Cagiotti MR, Camarda I, Carli E, Conti F, Fascetti S, Galasso G, Gubellini L, La Valva V, Lucchese F, Marchiori S, Mazzola P, Peccenini S, Pretto F, Poldini L, Prosser F, Siniscalco C, Villani MC, Viegi L, Wilhalm T, Blasi C (2009) The inventory of the non-native flora of Italy. Plant Biosystems 143: 386-430. https://doi.org/10.1080/11263500902722824

Celesti-Grapow L, Alessandrini A, Arrigoni PV, Assini S, Banfi E, Barni E, Bovio M, Brundu G, Cagiotti MR, Camarda I, Carli E, Conti F, Del Guacchio E, Domina G, Fascetti S, Galasso G, Gubellini L, Lucchese F, Medagli P, Passalacqua NG, Peccenini S, Poldini L, Pretto F, Prosser F, Vidali M, Viegi L, Villani MC, Wilhalm T, Blasi C (2010) Non-native flora of Italy: Species distribution and threats. Plant Biosystems 144: 12-28. https://doi. org/10.1080/11263500903431870

Çelik Y, Arisoy H (2013) Competitive analysis of outdoor ornamental plants sector: a case study of Konya province, Turkey. Journal of Horticultural Research 21(2): 5-16. https:// doi.org/10.2478/johr-2013-0016

Crawley MJ (2007) R book. John Wiley \& Sons, Chichester. https://doi.org/10.1002/9780470515075

DAISIE (2008) European Invasive Alien Species Gateway. http://www.europe-aliens.org/index.jsp Davis PH (Ed.) (1965-1985) Flora of Turkey and the East Aegean Islands, Vol. 1 (1965), Vol. 2 (1967), Vol. 3 (1970), Vol. 4 (1972), Vol. 5 (1975), Vol. 6 (1978), Vol. 7 (1982), Vol. 8 (1984), Vol. 9 (1985). Edinburgh University Press, Edinburgh.

Davis PH, Mill RR, Tan K (Eds) (1988) Flora of Turkey and the East Aegean Islands, Vol. 10. Edinburgh University Press, Edinburgh.

Dimopoulos P, Raus Th, Bergmeier E, Constantinidis Th, Iatrou G, Kokkini S, Strid A, Tzanoudakis D (2016) Vascular plants of Greece: An annotated checklist. Supplement. Willdenowia 46: 301-347. doi: http://dx.doi.org/10.3372/wi.46.46303 
Ekim T, Güner A (1986) The Anatolian Diagonal: fact or fiction? Proceedings of the Royal Society of Edinburgh, Section B: Biological Sciences 89: 69-77. https://doi.org/10.1017/ S0269727000008915

Ercisli S (2004) A short review of the fruit germplasm resources of Turkey. Genetic Resources and Crop Evolution 51: 419-435. https://doi.org/10.1023/B:GRES.0000023458.60138.79

Erginöz AM, Doğan E (1997) Türkiye’de Kıyı Alanları Yönetimi ve Yapılaşması. Arion Yayınları.

Essl F, Dullinger S, Rabitsch W, Hulme PE, Hülber K, Jarošík V, Kleinbauer I, Krausmann F, Kühn I, Nentwig W, Vilà M, Genovesi P, Gherardi F, Desprez-Lousteau M-L, Roques A, Pyšek P (2011) Socioeconomic legacy yields an invasion debt. Proceedings of the National Academy of Sciences of the United States of America 108: 203-207. https://doi. org/10.1073/pnas.1011728108

FAO (2017) FAOSTAT, Turkey country indicators. http://www.fao.org/faostat/en/\#country/223 [Accessed 23 February 2017]

Garnier E, Stahl U, Laporte M-A, Kattge J, Mougenot I, Kühn I, Laporte B, Amiaud B, Ahrestani FS, Bönisch G, Bunker, DE, Cornelissen JHC, Díaz S, Enquist BJ, Gachet S, Jaureguiberry P, Kleyer M, Lavorel S, Maicher L, Pérez-Harguindeguy N, Poorter H, Schildhauer M, Shipley B, Violle C, Weiher E, Wirth C, Wright IJ, Klotz S (2017) Towards a thesaurus of plant characteristics: an ecological contribution. Journal of Ecology 105: 298-309. https://doi.org/10.1111/1365-2745.12698

GBIF.org (2017) GBIF Occurrence. http://doi.org/10.15468/dl.7wm2qs [Download on 2nd January 2017]

Güner A (Ed.) (2014) Resimli Türkiye Florası, Ed. 1. Baskı, İstanbul. Türkiye İş Bankası Kültür Yayınları, İstanbul.

Güner A, Aslan S, Ekim T, Vural M, Babaç MT (Eds) (2012) Türkiye Bitkileri Listesi (Damarlı Bitkiler) [List of Turkey Plants]. Nezahat Gökyiğit Botanic Garden and Flora Research Society Publishing, Istanbul.

Güner A, Özhatay N, Ekim T, Başer KHC (Eds) (2000) Flora of Turkey and the East Aegean Islands, Vol. 11, Suppl. 2. Edinburgh University Press, Edinburgh.

Güneralp B, Tezer A, Albayrak I (2013) Local assessment of İstanbul: biodiversity and ecosystem services. In: Elmqvist T et al. (Eds) Urbanization, biodiversity and ecosystem services: challenges and opportunities: a global assessment. Springer Netherlands, 291-311. https:// doi.org/10.1007/978-94-007-7088-1_16

Hoffmann BD, Broadhurst LM (2016) The economic cost of managing invasive species in Australia. NeoBiota 31: 1-18. https://doi.org/10.3897/neobiota.31.6960

Jacobs LEO, Richardson DM, Lepschi BJ, Wilson JRU (2017) Quantifying errors and omissions in alien species lists: The introduction status of Melaleuca species in South Africa as a case study. NeoBiota 32: 89-105. https://doi.org/10.3897/neobiota.32.9842

Lambdon PW, Pyšek P, Basnou C, Hejda M, Arianoutsou M, Essl F, Jarošík V, Pergl J, Winter M, Anastasiu P, Andriopoulos P, Bazos I, Brundu G, Celesti-Grapow L, Chassot P, Delipetrou P, Josefsson M, Kark S, Klotz S, Kokkoris Y, Kühn I, Marchante H, Perglová I, Pino J, Vilà M, Zikos A, Roy D, Hulme PE (2008) Alien flora of Europe: species diversity, temporal trends, geographical patterns and research needs. Preslia 80: 101-149. 
Latombe G, Pyšek P, Jeschke JM, Blackburn TM, Bacher S, Capinha C, Costello MJ, Fernán$\operatorname{dez}$ M, Gregory RD, Hobern D, Hui C, Jetz W, Kumschick S, McGrannachan C, Pergl J, Roy HE, Scalera R, Squires ZE, Wilson JRU, Winter M, Genovesi P, McGeoch MA (2017) A vision for global monitoring of biological invasions. Biological Conservation (in press). https://doi.org/10.1016/j.biocon.2016.06.013

Nentwig W, Bacher S, Pyšek P, Vilà M, Kumschick S (2016) The Generic Impact Scoring System (GISS): a standardized tool to quantify the impacts of alien species. Environmental Monitoring and Assessment 188: 315. https://doi.org/10.1007/s10661-016-5321-4

Önen H (Ed.) (2015) Türkiye İstilâcı Bitkiler Kataloğu. Ezgi Ofset Matbaacılık, Ankara.

Özhatay N, Kültür Ş, Gürdal B (2013) Check-list of additional taxa to the Supplement Flora of Turkey VI. J. Fac. Pharm. Istanbul 43(1): 33-82.

Özhatay N, Kültür Ş, Gürdal B (2015) Check-list of additional taxa to the Supplement Flora of Turkey VII. J. Fac. Pharm. Istanbul 45(1): 61-86.

Pérez-Harguindeguy N, Díaz S, Garnier E, Lavorel S, Poorter H, Jaureguiberry P, Bret-Harte MS, Cornwell WK, Craine JM, Gurvich DE, Urcelay C, Veneklaas EJ, Reich PB, Poorter L, Wright IJ, Ray P, Enrico L, Pausas JG, de Vos AC, Buchmann N, Funes G, Quétier F, Hodgson JG, Thompson K, Morgan HD, ter Steege H, van der Heijden MGA, Sack L, Blonder B, Poschlod P, Vaieretti MV, Conti G, Staver AC, Aquino S, Cornelissen JHC (2016) New handbook for standardised measurement of plant functional traits worldwide. Australian Journal of Botany 64: 715-716. https://doi.org/10.1071/BT12225_CO

Pergl J, Sádlo J, Petrusek A, Laštůvka Z, Musil J, Perglová I, Šanda R, Šefrová H, Šíma J, Vohralík V, Pyšek P (2016a) Black, Grey and Watch Lists of alien species in the Czech Republic based on environmental impacts and management strategy. NeoBiota 28: 1-37. https://doi.org/10.3897/neobiota.28.4824

Pergl J, Sádlo J, Petř́k P, Danihelka J, Chrtek J Jr., Hejda M, Moravcová L, Perglová I, Štajerová K, Pyšek P (2016b) Dark side of the fence: ornamental plants as a source for spontaneous flora of the Czech Republic. Preslia 88: 163-184.

Pyšek P, Richardson DM, Rejmánek M, Webster G, Williamson M, Kirschner J (2004) Alien plants in checklists and floras: towards better communication between taxonomists and ecologists. Taxon 53: 131-143. https://doi.org/10.2307/4135498

Pyšek P, Danihelka J, Sádlo J, Chrtek Jr J, Chytrý M, Jarošík V, Kaplan Z, Krahulec F, Moravcová L, Pergl J, Štajerová K, Tichý L (2012) Catalogue of alien plants of the Czech Republic (2nd edition): checklist update, taxonomic diversity and invasion patterns. Preslia 84: 155-255.

Pyšek P, Jarošík V, Hulme PE, Kühn I, Wild J, Arianoutsou M, Bacher S, Chiron F, Didžiulis V, Essl F, Genovesi P, Gherardi F, Hejda M, Kark S, Lambdon PW, Desprez-Loustau A-M, Nentwig W, Pergl J, Poboljšaj K, Rabitsch W, Roques A, Roy DB, Shirley S, Solarz W, Vilà M, Winter M (2010) Disentangling the role of environmental and human pressures on biological invasions across Europe. Proceedings of the National Academy of Sciences of the United States of America 107: 12157-12162. https://doi.org/10.1073/ pnas. 1002314107

Pyšek P, Jarošík V, Pergl J, Randall R, Chytrý M, Kühn I, Tichý L, Danihelka J, Chrtek J jun, Sádlo J (2009) The global invasion success of Central European plants is related to distri- 
bution characteristics in their native range and species traits. Diversity and Distributions 15: 891-903. https://doi.org/10.1111/j.1472-4642.2009.00602.x

Pyšek P, Manceur AM, Alba C, McGregor KF, Pergl J, Štajerová K, Chytrý M, Danihelka J,

Kartesz J, Klimešová J, Lučanová M, Moravcová L, Nishino M, Sádlo J, Suda J, Tichý L, Kühn I (2015) Naturalization of central European plants in North America: species traits, habitats, propagule pressure, residence time. Ecology 96: 762-774. https://doi. org/10.1890/14-1005.1

R Core Team (2015) R: a language and environment for statistical computing v.3.1.2. R Foundation for Statistical Computing, Vienna.

Raunkiaer C (1934) The life-forms of plants and statistical plant geography. Clarendon Press, Oxford, UK.

Raunkiaer C (1937) Plant life forms. Claredon Press, Oxford, UK.

Řehák J, Řeháková B (1986) Analýza kategorizovaných dat v sociologii [Analysis of categorized data in sociology]. Academia, Prague.

Richardson DM, Pyšek P, Rejmánek M, Barbour MG, Panetta FD, West CJ (2000) Naturalization and invasion of alien plants: concepts and definitions. Diversity and Distributions 6: 93-107. https://doi.org/10.1046/j.1472-4642.2000.00083.x

Richardson DM, Pyšek P (2006) Plant invasions: merging the concepts of species invasiveness and community invasibility. Progress in Physical Geography 30: 409-431. https://doi. org/10.1191/0309133306pp490pr

Richardson DM, Pyšek P, Carlton JC (2011) A compendium of essential concepts and terminology in biological invasions. In: Richardson DM (Ed.) Fifty years of invasion ecology: the legacy of Charles Elton. Blackwell Publishing, Oxford, 409-420.

Roy HE, Peyton J, Aldridge DC, Bantock T, Blackburn TM, Britton R, Clark P, Cook E, Dehnen-Schmutz K, Dines T, Dobson M, Edwards F, Harrower C, Harvey MC, Minchin D, Noble DG, Parrott D, Pocock MJO, Preston CD, Roy S, Salisbury A, Schönrogge K, Sewell J, Shaw RH, Stebbing P, Stewart AJA, Walker KJ (2014) Horizon scanning for invasive alien species with the potential to threaten biodiversity in Great Britain. Global Change Biology 20: 3859-3871. https://doi.org/10.1111/gcb.12603

Rumlerová Z, Vilà M, Pergl J, Nentwig W, Pyšek P (2016) Scoring environmental and socioeconomic impacts of alien plants invasive in Europe. Biological Invasions 18: 3697-3711. https://doi.org/10.1007/s10530-016-1259-2

Saccardo PA (1909) Cronologia della flora Italiana. Padova. Tipografia del Seminario, 388 pp. Seebens H, Blackburn TM, Dyer EE, Genovesi P, Hulme PE, Jeschke JM, Pagad S, Pyšek P, Winter M, Arianoutsou M, Bacher S, Blasius B, Brundu G, Capinha C, Celesti-Grapow L, Dawson W, Dullinger S, Fuentes N, Jäger H, Kartesz J, Kenis M, Kreft H, Kühn I, Lenzner B, Liebhold A, Mosena A, Moser D, Nishino M, Pearman D, Pergl J, Rabitsch W, Rojas-Sandoval J, Roques A, Rorke S, Rossinelli S, Roy HE, Scalera R, Schindler S, Štajerová K, Tokarska-Guzik B, van Kleunen M, Walker K, Weigelt P, Yamanaka T, Essl F (2017) No saturation in the accumulation of alien species worldwide. Nature Communications 8: 14435. https://doi.org/10.1038/ncomms14435

Seebens H, Essl F, Dawson W, Fuentes N, Moser D, Pergl J, Pyšek P, van Kleunen M, Weber E, Winter M, Blasius B (2015) Global trade will accelerate plant invasions in emerging 
economies under climate change. Global Change Biology 21: 4128-4140. https://doi. org/10.1111/gcb.13021

Stevens PF (2001 onwards) Angiosperm phylogeny website. Version 12, July 2012 [and more or less continuously updated since]. http:/www.mobot.org/MOBOT/research/APweb/

Uludağ A, Aksoy N, Yazlık A, Arslan ZF, Yazmış E, Uremis I, Cossu T, Groom Q, Pergl J, Pyšek P, Brundu G (2017) Alien flora of Turkey: checklist, taxonomic composition and ecological attributes. https://doi.org/10.15468/7j1dof

Uremis I, Uludağ A, Arslan ZF, Abaci O (2014) A new record for the flora of Turkey: Eichhornia crassipes (Mart.) Solms (Pontederiaceae). EPPO Bulletin 44: 83-86. https://doi. org/10.1111/epp.12096

van Kleunen M, Dawson W, Essl F, Pergl J, Winter M, Weber E, Kreft H, Weigelt P, Kartesz J, Nishino M, Antonova LA, Barcelona JF, Cabezas FJ, Cárdenas D, Cárdenas-Toro J, Castaño N, Chacón E, Chatelain C, Ebel AL, Figueiredo E, Fuentes N, Groom QJ, Henderson L, Inderjit, Kupriyanov A, Masciadri S, Meerman J, Morozova O, Moser D, Nickrent DL, Patzelt A, Pelser PB, Baptiste MP, Poopath M, Schulze M, Seebens H, Shu W, Thomas J, Velayos M, Wieringa JJ, Pyšek P (2015) Global exchange and accumulation of non-native plants. Nature 525: 100-103. https://doi.org/10.1038/nature14910

Wilson JRU, García-Díaz P, Cassey P, Richardson DM, Pyšek P, Blackburn TM (2016) Biological invasions and natural colonisations are different: the need for invasion science. NeoBiota 31: 87-98. https://doi.org/10.3897/neobiota.31.9185

Winter M, Schweiger O, Klotz S, Nentwig W, Andriopoulos P, Arianoutsou M, Basnou C, Delipetrou P, Didžiulis V, Hejda M, Hulme PE, Lambdon PW, Pergl J, Pyšek P, Roy DB, Kühn I (2009) Plant extinctions and introductions lead to phylogenetic and taxonomic homogenization of the European flora. Proceedings of the National Academy of Sciences of the United States of America 106: 21721-21725. https://doi.org/10.1073/ pnas.0907088106

Woodford DJ, Richardson DM, MacIsaac HJ, Mandrak NE, van Wilgen BW, Wilson JRU, Weyl OLF (2016) Confronting the wicked problem of managing biological invasions. NeoBiota 31: 63-86. https://doi.org/10.3897/neobiota.31.10038 


\section{Appendix I}

Table A I. List of naturalized and casual alien taxa in the flora of Turkey. Taxa are ordered alphabetically. Each taxon is listed together with its family, residence time (Res: Arc = archaeophyte, Neo = neophyte); invasion status (Stat: Cas = casual, Nat $=$ naturalized), simplified growth form and native range.

\begin{tabular}{|c|c|c|c|c|c|}
\hline Taxa & Family & Res & Stat & \begin{tabular}{|l} 
Simplified \\
growth form
\end{tabular} & Native range \\
\hline Abutilon theophrastii Medik. & Malvaceae & Arc & Nat & Herb & Asia \\
\hline Acacia dealbata Link & Fabaceae & Neo & Cas & Tree & Australia \\
\hline Acacia karroo Hayne & Fabaceae & Neo & Nat & Tree & Africa \\
\hline Acacia longifolia (Andrews) Willd. & Fabaceae & Neo & Nat & Tree & Australia \\
\hline Acacia mearnsii De Wild. & Fabaceae & Neo & Nat & Tree & Australia \\
\hline Acacia retinodes Schltdl. & Fabaceae & Neo & Nat & Tree & Australia \\
\hline Acacia saligna (Labill.) H.L.Wendl. & Fabaceae & $\mathrm{Neo}$ & Nat & Tree & Australia \\
\hline Acalypha australis L. & Euphorbiaceae & Neo & Nat & Herb & Asia \\
\hline Acer buergerianum Miq. & Sapindaceae & Neo & Nat & Tree & Asia \\
\hline Acer negundo L. & Sapindaceae & Neo & Nat & Tree & America \\
\hline Acer palmatum Thunb. & Sapindaceae & Arc & Nat & Tree & Asia \\
\hline Acer saccharum Marsh. & Sapindaceae & Neo & Cas & Tree & America \\
\hline Acorus calamus $\mathrm{L}$. & Acoraceae & Arc & Nat & Aquatic & Asia \\
\hline $\begin{array}{l}\text { Actinidia deliciosa (A.Chev.) C.F.Liang \& } \\
\text { A.R.Ferguson }\end{array}$ & Actinidiaceae & Neo & Cas & Vine & Asia \\
\hline Aesculus carnea J.Zeyh. & Sapindaceae & Neo & Nat & Tree & Garden/Hybrid \\
\hline Aesculus hippocastanum L. & Sapindaceae & Neo & Nat & Tree & Europe \\
\hline Agave americana L. var. americana & Asparagaceae & Neo & Nat & Succulent & America \\
\hline Agave americana var. striata Trel. & Asparagaceae & Neo & Nat & Succulent & America \\
\hline Agrostemma githago L. & Caryophyllaceae & Arc & Nat & Herb & Mediterranean \\
\hline Ailanthus altissima (Mill.) Swingle & Simaroubaceae & Neo & Nat & Tree & Asia \\
\hline Albizia julibrissin Durazz & Fabaceae & Neo & Nat & Tree & Asia \\
\hline Alternanthera sessilis (L.) R.Br. ex DC. & Amaranthaceae & $\mathrm{Neo}$ & Nat & Herb & Asia \\
\hline Amaranthus albus L. & Amaranthaceae & Arc & Nat & Herb & America \\
\hline Amaranthus blitoides S. Watson & Amaranthaceae & Arc & Nat & Herb & America \\
\hline Amaranthus blitum L. subsp. blitum & Amaranthaceae & Arc & Nat & Herb & Eurasia \\
\hline $\begin{array}{l}\text { Amaranthus blitum subsp. emarginatus (Salzm. } \\
\text { ex Uline \& Bray) Carretero, Muñoz Garm. \& } \\
\text { Pedrol }\end{array}$ & Amaranthaceae & Arc & Nat & Herb & Eurasia \\
\hline Amaranthus blitum subsp. oleraceus (L.) Costea & Amaranthaceae & Arc & Nat & Herb & Eurasia \\
\hline Amaranthus cruentus $\mathrm{L}$. & Amaranthaceae & $\mathrm{Neo}$ & Nat & Herb & America \\
\hline Amaranthus deflexus $\mathrm{L}$. & Amaranthaceae & Neo & Nat & Herb & America \\
\hline Amaranthus graecizans $\mathrm{L}$. & Amaranthaceae & Neo & Nat & Herb & Mediterranean \\
\hline Amaranthus hybridus $\mathrm{L}$. & Amaranthaceae & Neo & Nat & Herb & America \\
\hline Amaranthus hypochondriacus L. & Amaranthaceae & Neo & Nat & Herb & America \\
\hline Amaranthus retroflexus $\mathrm{L}$. & Amaranthaceae & Neo & Nat & Herb & America \\
\hline Amaranthus spinosus $\mathrm{L}$. & Amaranthaceae & Neo & Nat & Herb & America \\
\hline Amaranthus viridis $\mathrm{L}$. & Amaranthaceae & Neo & Nat & Herb & America \\
\hline Ambrosia artemisiifolia $\mathrm{L}$. & Asteraceae & Neo & Nat & Herb & America \\
\hline Ambrosia tenuifolia Spreng. & Asteraceae & Neo & Nat & Herb & America \\
\hline
\end{tabular}




\begin{tabular}{|c|c|c|c|c|c|}
\hline Taxa & Family & Res & Stat & $\begin{array}{l}\text { Simplified } \\
\text { growth form }\end{array}$ & Native range \\
\hline Ammannia coccinea Rottb. & Lythraceae & $\mathrm{Neo}$ & Nat & Herb & America \\
\hline Amorpha fruticosa $\mathrm{L}$. & Fabaceae & Neo & Cas & Shrub & America \\
\hline Araujia sericifera Brot. & Apocynaceae & Neo & Nat & Vine & America \\
\hline Armeria maritima (Mill.) Willd. & Plumbaginaceae & Arc & Cas & Herb & Europe \\
\hline Artemisia annua $\mathrm{L}$. & Asteraceae & $\mathrm{Neo}$ & Nat & Herb & Asia \\
\hline Artemisia verlotiorum Lamotte & Asteraceae & $\mathrm{Neo}$ & Nat & Herb & Asia \\
\hline Arundo donax $\mathrm{L}$. & Poaceae & Arc & Nat & Bambusoid & Asia \\
\hline Aster subulatus (Michx.) Hort. ex Michx. & Asteraceae & Neo & Nat & Herb & America \\
\hline Avena byzantina K.Koch & Poaceae & Arc & Cas & Herb & Garden/Hybrid \\
\hline Azolla filiculoides Lam. & Azollaceae & Arc & Nat & Aquatic & America \\
\hline Bauhinia variegata $\mathrm{L}$. & Fabaceae & $\mathrm{Neo}$ & Nat & Tree & Asia \\
\hline Berberis veitchii C.K.Schneid. & Berberidaceae & Arc & Nat & Shrub & Asia \\
\hline Berberis thunbergii DC. & Berberidaceae & Arc & Nat & Shrub & Asia \\
\hline Bidens bipinnata $\mathrm{L}$. & Asteraceae & $\mathrm{Neo}$ & Nat & Herb & Asia \\
\hline Bidens campylotheca Sch.Bip. & Asteraceae & Neo & Nat & Herb & America \\
\hline Bidens cernua L. s.l. & Asteraceae & Neo & Nat & Herb & America \\
\hline Bidens frondosa $\mathrm{L}$. & Asteraceae & Neo & Nat & Herb & America \\
\hline Bougainvillea buttiana Holttum \& Standl. & Nyctaginaceae & Neo & Nat & Vine & America \\
\hline Bougainvillea glabra Choisy & Nyctaginaceae & Neo & Cas & Vine & America \\
\hline Bougainvillea spectabilis Willd. & Nyctaginaceae & $\mathrm{Neo}$ & Nat & Vine & America \\
\hline Brachychiton populneus (Schott \& Endl.) R.Br. & Sterculiaceae & Neo & Nat & Tree & Australia \\
\hline Bromus tectorum L. & Poaceae & N/A & Nat & Herb & Eurasia \\
\hline Broussonetia papyrifera (L.) L'Hér. ex Vent. & Moraceae & Neo & Nat & Tree & Asia \\
\hline Bryophyllum delagoense (Eckl. \& Zeyh.) Druce & Crassulaceae & Neo & Cas & Succulent & Africa \\
\hline Buddleja davidii Franch. & Scrophulariaceae & Neo & Nat & Shrub & Asia \\
\hline Caesalpinia gilliesii (Hook.) D.Dietr. & Fabaceae & $\mathrm{Neo}$ & Nat & Shrub & America \\
\hline Calendula officinalis $\mathrm{L}$. & Asteraceae & Arc & Nat & Herb & Eurasia \\
\hline Callistemon citrinus (Curtis) Skeels & Myrtaceae & $\mathrm{Neo}$ & Cas & Tree & Australia \\
\hline Callistemon viminalis (Sol. ex Gaertn.) G.Don & Myrtaceae & Neo & Cas & Tree & Australia \\
\hline Camellia japonica L. & Theaceae & Arc & Nat & Shrub & Asia \\
\hline Canna indica $\mathrm{L}$. & Cannaceae & Neo & Nat & Bambusoid & America \\
\hline Caragana arborescens Lam. & Fabaceae & Neo & Nat & Shrub/Tree & Asia \\
\hline Carex vulpinoidea Michx. & Cyperaceae & Neo & Nat & Herb & America \\
\hline Carpobrotus acinaciformis (L.) L.Bolus & Aizoaceae & Neo & Nat & Succulent & Africa \\
\hline Carpobrotus edulis (L.) N.E.Br. & Aizoaceae & Neo & Nat & Succulent & Africa \\
\hline Carthamus tinctorius $\mathrm{L}$. & Asteraceae & Arc & Cas & Herb & Asia \\
\hline Cascabela thevetia (L.) Lippold & Apocynaceae & Neo & Cas & Tree & America \\
\hline Catalpa bignonioides Walter & Bignoniaceae & Neo & Nat & Tree & America \\
\hline Cedrus atlantica (Endl.) Carrière & Pinaceae & Neo & Cas & Tree & Africa \\
\hline Cedrus deodara (Roxb. ex D.Don) G.Don & Pinaceae & $\mathrm{Neo}$ & Nat & Tree & Asia \\
\hline Ceiba speciosa (A.St.-Hil.) Ravenna & Malvaceae & $\mathrm{Neo}$ & Nat & Tree & America \\
\hline Cenchrus incertus M.A.Curtis & Poaceae & Arc & Nat & Herb & America \\
\hline Centaurea pullata L. & Asteraceae & Arc & Nat & Herb & Mediterranean \\
\hline Chaenomeles japonica (Thunb.) Lindl. ex Spach & Rosaceae & $\mathrm{Neo}$ & Cas & Shrub & Asia \\
\hline Chenopodium album $\mathrm{L}$. & Amaranthaceae & Arc & Nat & Herb & Eurasia \\
\hline
\end{tabular}




\begin{tabular}{|c|c|c|c|c|c|}
\hline Taxa & Family & Res & Stat & $\begin{array}{l}\text { Simplified } \\
\text { growth form }\end{array}$ & Native range \\
\hline Chenopodium giganteum D.Don & Chenopodiaceae & Arc & Nat & Herb & Asia \\
\hline Cichorium endivia L. & Asteraceae & Arc & Cas & Herb & Asia \\
\hline Citrullus colocynthis (L.) Schrad. & Cucurbitaceae & Arc & Cas & Vine & Eurasia \\
\hline Citrus trifoliata $\mathrm{L}$. & Rutaceae & $\mathrm{Neo}$ & Cas & Tree & Asia \\
\hline Coix lacryma-jobi $\mathrm{L}$. & Poaceae & $\mathrm{Neo}$ & Nat & Herb & Asia \\
\hline Commelina communis $\mathrm{L}$. & Commelinaceae & $\mathrm{Neo}$ & Nat & Herb & Asia \\
\hline Convolvulus tricolor $\mathrm{L}$. & Convolvulaceae & Arc & Cas & Vine & Mediterranean \\
\hline $\begin{array}{l}\text { Cortaderia selloana (Schult. \& Schult.f.) Asch. } \\
\& \text { Graebn. }\end{array}$ & Poaceae & Neo & Cas & Bambusoid & America \\
\hline Cosmos bipinnatus Cav. & Asteraceae & Neo & Cas & Herb & America \\
\hline Cotoneaster adpressus Bois & Rosaceae & Neo & Cas & Shrub & Asia \\
\hline Cotoneaster franchetii Bois & Rosaceae & Neo & Nat & Shrub & Asia \\
\hline Cotoneaster horizontalis Decne. & Rosaceae & Neo & Nat & Shrub & Asia \\
\hline Cotoneaster salicifolius Franch. & Rosaceae & Arc & Nat & Shrub & Asia \\
\hline Crassocephalum crepidioides (Benth.) S.Moore & Asteraceae & Neo & Nat & Herb & Africa \\
\hline Cryptomeria japonica (Thunb. ex L.f.) D.Don & Cupressaceae & Neo & Cas & Tree & Asia \\
\hline Cupressus arizonica Greene & Cupressaceae & Neo & Nat & Tree & America \\
\hline Cupressus macrocarpa Hartw. & Cupressaceae & $\mathrm{Neo}$ & Nat & Tree & America \\
\hline Cuscuta campestris Yunck. & Cuscutaceae & Neo & Nat & Herb & America \\
\hline Cymbalaria muralis P.Gaertn., B.Mey. \& Scherb. & Plantaginaceae & Arc & Nat & Herb & Mediterranean \\
\hline $\begin{array}{l}\text { Cynoglossum wallichii var. glochidiatum (Wall. ex } \\
\text { Benth.) Kazmi }\end{array}$ & Boraginaceae & Arc & Nat & Herb & Asia \\
\hline Cyperus congestus Vahl & Cyperaceae & $\mathrm{Neo}$ & Nat & Herb & Africa \\
\hline Cyperus esculentus $\mathrm{L}$. & Cyperaceae & Arc & Nat & Herb & Unknown \\
\hline Cyperus rotundus $\mathrm{L}$. & Cyperaceae & Arc & Nat & Herb & Eurasia \\
\hline Dalbergia sissoo DC. & Fabaceae & Neo & Cas & Tree & Asia \\
\hline Datura innoxia Mill. & Solanaceae & Neo & Nat & Herb & America \\
\hline Datura metel L. & Solanaceae & Neo & Cas & Herb & Asia \\
\hline Datura stramonium L. & Solanaceae & $\mathrm{Neo}$ & Nat & Herb & America \\
\hline Deutzia gracilis Siebold \& Zucc. & Hydrangeaceae & Arc & Nat & Shrub & Asia \\
\hline Deutzia scabra Thunb. & Hydrangeaceae & Neo & Nat & Shrub & Asia \\
\hline Dichondra repens J.R.Forst. \& G.Forst. & Convolvulaceae & Neo & Cas & Herb & Asia \\
\hline Dichrocephala integrifolia (L.f.) Kuntze & Asteraceae & Neo & Nat & Herb & Africa \& Asia \\
\hline Dieffenbachia seguine (Jacq.) Schott & Araceae & Neo & Nat & Herb & America \\
\hline Digitaria sanguinalis (L.) Scop. & Poaceae & Neo & Nat & Herb & \begin{tabular}{|l|} 
Europe \& \\
Africa
\end{tabular} \\
\hline Diplachne fusca (L.) P.Beauv. & Poaceae & Neo & Nat & Herb & Unknown \\
\hline Duchesnea indica (Jacks.) Focke & Rosaceae & Neo & Cas & Herb & Asia \\
\hline Duranta erecta L. & Verbenaceae & $\mathrm{Neo}$ & Nat & Shrub/Tree & America \\
\hline $\begin{array}{l}\text { Dysphania ambrosioides (L.) Mosyakin \& } \\
\text { Clemants }\end{array}$ & Amaranthaceae & Neo & Nat & Herb & America \\
\hline Dysphania botrys (L.) Mosyakin \& Clemants & Amaranthaceae & Arc & Nat & Herb & Eurasia \\
\hline Dysphania multifida (L.) Mosyakin \& Clemants & Amaranthaceae & Neo & Nat & Herb & America \\
\hline Echinochloa colonum (L.) Link & Poaceae & Neo & Nat & Herb & Unknown \\
\hline Echinochloa oryzoides (Ard.) Fritsch & Poaceae & Arc & Nat & Herb & Asia \\
\hline Echinopsis chamaecereus H.Friedrich \& Glaetzle & Cactaceae & $\mathrm{Neo}$ & Nat & Succulent & America \\
\hline
\end{tabular}




\begin{tabular}{|c|c|c|c|c|c|}
\hline Taxa & Family & Res & Stat & \begin{tabular}{|l}
$\begin{array}{l}\text { Simplified } \\
\text { growth form }\end{array}$ \\
\end{tabular} & Native range \\
\hline Egeria densa Planch. & Hydrocharitaceae & $\mathrm{Neo}$ & Nat & Aquatic & America \\
\hline Eichhornia crassipes (Mart.) Solms & Pontederiaceae & Neo & Nat & Aquatic & America \\
\hline Elatine ambigua Wight & Elatinaceae & Neo & Nat & Aquatic & Asia \\
\hline Eleusine indica (L.) Gaertn. & Poaceae & $\mathrm{Neo}$ & Nat & Herb & Africa \\
\hline Elodea canadensis Michx. & Hydrocharitaceae & $\mathrm{Neo}$ & Nat & Aquatic & America \\
\hline Elsholtzia ciliata (Thunb.) Hyl. & Lamiaceae & $\mathrm{Neo}$ & Nat & Herb & Asia \\
\hline Eragrostis curvula (Schrad.) Nees & Poaceae & Arc & Nat & Herb & Africa \\
\hline Erigeron annuus (L.) Pers. & Asteraceae & $\mathrm{Neo}$ & Nat & Herb & America \\
\hline Erigeron bonariensis $\mathrm{L}$. & Asteraceae & Neo & Nat & Herb & America \\
\hline Erigeron canadensis $\mathrm{L}$. & Asteraceae & Neo & Nat & Herb & America \\
\hline Erigeron sumatrensis Retz. & Asteraceae & $\mathrm{Neo}$ & Nat & Herb & America \\
\hline Erythrina crista-galli L. & Fabaceae & $\mathrm{Neo}$ & Cas & Tree & America \\
\hline Erythrina flabelliformis Kearney & Fabaceae & $\mathrm{Neo}$ & Cas & Tree & America \\
\hline Eucalyptus camaldulensis Dehnh. & Myrtaceae & $\mathrm{Neo}$ & Cas & Tree & Australia \\
\hline Eucalyptus grandis W.Hill & Myrtaceae & Neo & Cas & Tree & Australia \\
\hline Euonymus fortunei (Turcz.) Hand.-Mazz. & Celastraceae & Arc & Nat & Shrub & Asia \\
\hline Euonymus japonicus Thunb. & Celastraceae & Arc & Nat & Shrub/Tree & Asia \\
\hline Eupatorium cannabinum L. & Asteraceae & Arc & Nat & Herb & Europe \\
\hline Euphorbia chamaesyce L. & Euphorbiaceae & Neo & Nat & Herb & America \\
\hline Euphorbia heterophylla L. & Euphorbiaceae & $\mathrm{Neo}$ & Cas & Herb & America \\
\hline Euphorbia humifusa Willd. & Euphorbiaceae & Arc & Nat & Herb & Asia \\
\hline Euphorbia lagascae Spreng. & Euphorbiaceae & Arc & Nat & Herb & Mediterranean \\
\hline Euphorbia lathyris L. & Euphorbiaceae & Arc & Nat & Herb & Mediterranean \\
\hline Euphorbia nutans Lag. & Euphorbiaceae & Neo & Nat & Herb & America \\
\hline Euphorbia prostrata Aiton & Euphorbiaceae & Neo & Nat & Herb & America \\
\hline Euphorbia serpens Kunth & Euphorbiaceae & $\mathrm{Neo}$ & Nat & Herb & America \\
\hline Euphorbia supina Rafin. & Euphorbiaceae & $\mathrm{Neo}$ & Nat & Herb & America \\
\hline Fallopia aubertii (L.Henry) Holub & Polygonaceae & $\mathrm{Neo}$ & Nat & Vine & Asia \\
\hline Fatsia japonica (Thunb.) Decne. \& Planch. & Araliaceae & Neo & Nat & Shrub/Tree & Asia \\
\hline Ficus elastica Roxb. ex Hornem. & Moraceae & Neo & Cas & Tree & Asia \\
\hline Ficus macrophylla Desf. ex Pers. & Moraceae & Neo & Cas & Tree & Australia \\
\hline Ficus microcarpa L.f. & Moraceae & Neo & Cas & Tree & Asia \\
\hline Forsythia $\times$ intermedia Zabel & Oleaceae & Neo & Cas & Shrub & Garden/Hybrid \\
\hline $\begin{array}{l}\text { Fragaria } \times \text { ananassa (Duchesne ex Weston) } \\
\text { Duchesne ex Rozier }\end{array}$ & Rosaceae & Neo & Cas & Herb & America \\
\hline Gaillardia pulchella Foug. & Asteraceae & Neo & Cas & Herb & America \\
\hline Galinsoga ciliata (Rafin) S.F. Blake & Asteraceae & Neo & Nat & Herb & America \\
\hline Galinsoga parviflora Cav. & Asteraceae & Neo & Nat & Herb & America \\
\hline Galinsoga quadriradiata Ruiz \& Pav. & Asteraceae & Neo & Nat & Herb & America \\
\hline Gasteria obliqua (Aiton) Duval & Xanthorrhoeaceae & Neo & Cas & Succulent & Africa \\
\hline Gazania rigens (L.) Gaertn. & Asteraceae & Neo & Cas & Herb & Africa \\
\hline Geranium pusillum L. & Geraniaceae & Neo & Nat & Herb & Eurasia \\
\hline Gleditsia triacanthos $\mathrm{L}$. & Fabaceae & Neo & Cas & Tree & America \\
\hline Gomphocarpus fruticosus (L.) W.T.Aiton & Apocynaceae & $\mathrm{Neo}$ & Nat & Herb & Africa \\
\hline Gypsophila elegans M.Bieb. & Caryophyllaceae & Arc & Nat & Herb & Eurasia \\
\hline
\end{tabular}




\begin{tabular}{|c|c|c|c|c|c|}
\hline Taxa & Family & Res & Stat & \begin{tabular}{|l|}
$\begin{array}{l}\text { Simplified } \\
\text { growth form }\end{array}$ \\
\end{tabular} & Native range \\
\hline Gypsophila pilosa Huds. & Caryophyllaceae & Arc & Nat & Herb & Asia \\
\hline Heliotropium curassavicum L. & Boraginaceae & Neo & Nat & Herb & America \\
\hline Hemerocallis fulva (L.) L. & Hemerocallidaceae & Neo & Nat & Herb & Asia \\
\hline Hibiscus trionum $\mathrm{L}$. & Malvaceae & Arc & Nat & Herb & Africa \\
\hline $\begin{array}{l}\text { Homalocladium platycladum (F.Muell.) } \\
\text { L.H.Bailey }\end{array}$ & Polygonaceae & Neo & Cas & Shrub & Oceania \\
\hline Hoya carnosa (L.f.) R.Br. & Apocynaceae & Neo & Cas & Vine & Asia \\
\hline Hydrangea macrophylla (Thunb.) Ser. & Hydrangeaceae & Neo & Nat & Herb & Asia \\
\hline Hydrocotyle ramiflora Maxim. & Umbelliferae & Neo & Nat & Aquatic & Asia \\
\hline Imperata cylindrica (L.) Raeusch. & Poaceae & Neo & Nat & Herb & Asia \\
\hline Ipomoea nil (L.) Roth & Convolvulaceae & Neo & Nat & Vine & America \\
\hline Ipomoea purpurea (L.) Roth & Convolvulaceae & Neo & Nat & Vine & America \\
\hline Ipomoea tricolor Cav. & Convolvulaceae & Neo & Nat & Vine & America \\
\hline Ipomoea triloba $\mathrm{L}$. & Convolvulaceae & Neo & Nat & Vine & America \\
\hline Jacaranda mimosifolia D.Don & Bignoniaceae & Neo & Cas & Tree & America \\
\hline Juncus tenuis Willd. & Juncaceae & Neo & Nat & Herb & America \\
\hline Juniperus chinensis L. & Cupressaceae & $\mathrm{Neo}$ & Nat & Shrub/Tree & Asia \\
\hline Juniperus horizontalis Moench & Cupressaceae & Neo & Nat & Shrub & America \\
\hline Justicia brandegeeana Wassh. \& L.B.Sm. & Acanthaceae & Neo & Cas & Shrub & America \\
\hline Kalanchoe blossfeldiana Poelln. & Crassulaceae & Neo & Cas & Succulent & $\begin{array}{l}\begin{array}{l}\text { Africa } \\
\text { (Madagascar) }\end{array} \\
\end{array}$ \\
\hline Kerria japonica (L.) DC. & Rosaceae & Neo & Cas & Shrub & Asia \\
\hline Kniphofia uvaria (L.) Oken & Liliaceae & Neo & Cas & Succulent & Africa \\
\hline Koelreuteria paniculata Laxm. & Sapindaceae & Neo & Cas & Tree & Asia \\
\hline Lagerstroemia indica $\mathrm{L}$. & Lythraceae & Neo & Cas & Tree & Asia \\
\hline Lantana camara $\mathrm{L}$. & Verbenaceae & Neo & Cas & Shrub & America \\
\hline Lepidium virginicum $\mathrm{L}$. & Brassicaceae & Neo & Nat & Herb & America \\
\hline Leucaena leucocephala (Lam.) de Wit & Fabaceae & Neo & Cas & Tree & America \\
\hline Ligustrum ovalifolium Hassk. & Oleaceae & Neo & Cas & Shrub/Tree & Asia \\
\hline Liquidambar styraciflua $\mathrm{L}$. & Altingiaceae & Neo & Cas & Tree & America \\
\hline Livistona mariae F.Muell. & Arecaceae & Neo & Cas & Palm & Australia \\
\hline Lonicera japonica Thunb. & Caprifoliaceae & Neo & Cas & Vine & Asia \\
\hline Lonicera ligustrina var. yunnanensis Franch. & Caprifoliaceae & Neo & Cas & Vine & Asia \\
\hline Lonicera periclymenum $\mathrm{L}$. & Caprifoliaceae & Neo & Nat & Vine & $\begin{array}{l}\text { Europe \& NW } \\
\text { Africa }\end{array}$ \\
\hline Ludwigia peploides (Kunth) P.H.Raven s.l. & Onagraceae & Neo & Cas & Aquatic & America \\
\hline Lycianthes rantonnei (Carrière) Bitter & Solanaceae & Neo & Nat & Shrub & America \\
\hline Lysimachia japonica Thunb. & Primulaceae & Neo & Nat & Herb & Asia \\
\hline Maclura pomifera (Raf.) C.K.Schneid. & Moraceae & Neo & Nat & Tree & America \\
\hline Magnolia grandiflora L. & Magnoliaceae & Neo & Cas & Tree & America \\
\hline Malus floribunda Siebold ex Van Houtte & Rosaceae & Arc & Nat & Shrub/Tree & Asia \\
\hline Matricaria discoidea DC. & Asteraceae & Neo & Nat & Herb & America \\
\hline Matricaria matricarioides (Less.) Porter & Asteraceae & Neo & Nat & Herb & America \\
\hline Melia azedarach L. & Meliaceae & Neo & Nat & Tree & Asia \\
\hline Mesembryanthemum cordifolium L.f. & Aizoaceae & Neo & Nat & Succulent & Africa \\
\hline Mesembryanthemum crystallinum $\mathrm{L}$. & Aizoaceae & Neo & Nat & Succulent & Africa \\
\hline
\end{tabular}




\begin{tabular}{|c|c|c|c|c|c|}
\hline Taxa & Family & Res & Stat & \begin{tabular}{|l|}
$\begin{array}{l}\text { Simplified } \\
\text { growth form }\end{array}$ \\
\end{tabular} & Native range \\
\hline Mesembryanthemum nodiflorum $\mathrm{L}$. & Aizoaceae & Arc & Nat & Succulent & $\begin{array}{l}\text { Mediterranean } \\
\& \text { S Africa }\end{array}$ \\
\hline Microstegium vimineum (Trin.) A.Camus & Poaceae & Neo & Nat & Herb & Asia \\
\hline Mirabilis jalapa $\mathrm{L}$. & Nyctaginaceae & Neo & Cas & Herb & America \\
\hline Miscanthus sinensis Andersson & Poaceae & Neo & Cas & Bambusoid & Asia \\
\hline Myriophyllum spicatum $\mathrm{L}$. & Haloragaceae & $\mathrm{Neo}$ & Cas & Aquatic & Eurasia \\
\hline Myriophyllum verticillatum $\mathrm{L}$. & Haloragaceae & $\mathrm{Neo}$ & Cas & Aquatic & Circumboreal \\
\hline Nandina domestica Thunb. & Berberidaceae & Neo & Cas & Bambusoid & Asia \\
\hline Nephrolepis exaltata (L.) Schott & Nephrolepidaceae & Neo & Cas & Fern & America \\
\hline Nicotiana glauca Graham & Solanaceae & Neo & Nat & Shrub/Tree & America \\
\hline Oenothera biennis L. & Onagraceae & Neo & Nat & Herb & America \\
\hline Oenothera glazioviana Micheli & Onagraceae & $\mathrm{Neo}$ & Nat & Herb & Garden/Hybrid \\
\hline Oenothera parodiana Munz & Onagraceae & Neo & Nat & Herb & America \\
\hline Oldenlandia capensis L.f. var. capensis & Rubiaceae & $\mathrm{Neo}$ & Nat & Herb & Africa \\
\hline Oldenlandia capensis var. pleiosepala Bremek. & Rubiaceae & Neo & Cas & Herb & Africa \\
\hline Opuntia ficus-indica (L.) Mill. & Cactaceae & $\mathrm{Neo}$ & Nat & Succulent & America \\
\hline Opuntia microdasys (Lehm.) Pfeiff. & Cactaceae & Neo & Nat & Succulent & America \\
\hline Oryza sativa $\mathrm{L}$. & Poaceae & Arc & Cas & Herb & Asia \\
\hline Oxalis articulata Savigny & Oxalidaceae & Neo & Nat & Herb & America \\
\hline Oxalis corniculata L. s.l. & Oxalidaceae & Arc & Nat & Herb & America \\
\hline Oxalis debilis var. corymbosa (DC.) Lourteig & Oxalidaceae & $\mathrm{Neo}$ & Nat & Herb & America \\
\hline Oxalis floribunda Lehm. & Oxalidaceae & Neo & Nat & Herb & America \\
\hline Oxalis pes-caprae $\mathrm{L}$. & Oxalidaceae & Neo & Nat & Herb & Africa \\
\hline Oxalis pes-caprae f. pleniflora (Lowe) Sunding & Oxalidaceae & Neo & Nat & Herb & Africa \\
\hline Oxalis stricta $\mathrm{L}$. & Oxalidaceae & Neo & Nat & Herb & America \\
\hline Panicum capillare $\mathrm{L}$. & Poaceae & Neo & Nat & Herb & America \\
\hline Panicum miliaceum L. & Poaceae & Arc & Nat & Herb & Asia \\
\hline Parkinsonia aculeata $\mathrm{L}$. & Fabaceae & $\mathrm{Neo}$ & Cas & Tree & America \\
\hline Parthenocissus quinquefolia (L.) Planch. & Vitaceae & $\mathrm{Neo}$ & Cas & Vine & America \\
\hline Paspalum dilatatum Poir. & Poaceae & Neo & Nat & Herb & America \\
\hline Paspalum distichum $\mathrm{L}$. & Poaceae & $\mathrm{Neo}$ & Nat & Herb & America \\
\hline Paspalum thunbergii Kunth ex Steud & Poaceae & Arc & Cas & Herb & Asia \\
\hline Passiflora caerulea L. & Passifloraceae & Neo & Cas & Vine & America \\
\hline Paulownia elongata S. Y. Hu. & Paulowniaceae & $\mathrm{Neo}$ & Cas & Tree & Asia \\
\hline Paulownia fortunei (Seem.) Hemsl. & Paulowniaceae & Neo & Cas & Tree & Asia \\
\hline Paulownia fortunei $x$ Paulownia tomentosa & Paulowniaceae & Neo & Cas & Tree & Garden/Hybrid \\
\hline Paulownia tomentosa Steud. & Paulowniaceae & Neo & Cas & Tree & Asia \\
\hline Pelargonium zonale (L.) L'Hér. ex Aiton & Geraniaceae & Neo & Nat & Shrub & Africa \\
\hline Perilla frutescens (L.) Britton & Lamiaceae & Neo & Cas & Herb & Asia \\
\hline Phacelia tanacetifolia Benth. & Hydrophyllaceae & Neo & Cas & Herb & America \\
\hline Phaseolus vulgaris $\mathrm{L}$. & Fabaceae & Neo & Cas & Vine & America \\
\hline Phyla canescens (Kunth) Greene & Verbenaceae & Neo & Nat & Herb & America \\
\hline Phyla nodiflora (L.) Greene & Verbenaceae & $\mathrm{Neo}$ & Nat & Herb & America \\
\hline Phyllostachys bambusoides Siebold \& Zucc. & Poaceae & $\mathrm{Neo}$ & Nat & Bambusoid & Asia \\
\hline Physalis alkekengi L. s.l. & Solanaceae & Neo & Nat & Herb & Eurasia \\
\hline
\end{tabular}




\begin{tabular}{|c|c|c|c|c|c|}
\hline Taxa & Family & Res & Stat & $\begin{array}{l}\text { Simplified } \\
\text { growth form }\end{array}$ & Native range \\
\hline Physalis angulata $\mathrm{L}$. & Solanaceae & $\mathrm{Neo}$ & Nat & Herb & America \\
\hline Physalis philadelphica var. immaculata Waterf. & Solanaceae & Neo & Nat & Herb & America \\
\hline Physalis pubescens L. & Solanaceae & Neo & Nat & Herb & America \\
\hline Phytolacca americana $\mathrm{L}$. & Phytolaccaceae & $\mathrm{Neo}$ & Nat & Herb & America \\
\hline Picea glauca (Moench) Voss & Pinaceae & $\mathrm{Neo}$ & Nat & Tree & America \\
\hline Pinus pinaster Aiton & Pinaceae & Arc & Nat & Tree & Mediterranean \\
\hline Pinus ponderosa Douglas ex C.Lawson & Pinaceae & Neo & Nat & Tree & America \\
\hline Pinus radiata D.Don & Pinaceae & Neo & Cas & Tree & America \\
\hline Pittosporum tobira (Thunb.) W.T.Aiton & Pittosporaceae & Neo & Cas & Shrub & Asia \\
\hline Platycladus orientalis (L.) Franco & Cupressaceae & Neo & Nat & Tree & Asia \\
\hline Plumbago auriculata Lam. & Plumbaginaceae & Neo & Cas & Shrub & Africa \\
\hline Polygala myrtifolia L. & Polygalaceae & $\mathrm{Neo}$ & Cas & Shrub & Africa \\
\hline Polygonum perfoliatum L. & Polygonaceae & $\mathrm{Neo}$ & Nat & Vine & Asia \\
\hline Polygonum thunbergii Siebold \& Zucc. & Polygonaceae & Arc & Nat & Herb & Asia \\
\hline Populus $\times$ canadensis Moench & Salicaceae & Neo & Nat & Tree & Garden/Hybrid \\
\hline Populus deltoides Bartr. ex Marsh. & Salicaceae & Neo & Nat & Tree & America \\
\hline Portulaca grandiflora Hook. & Portulacaceae & Neo & Cas & Herb & America \\
\hline Portulaca oleracea L. s.l. & Portulacaceae & Arc & Nat & Herb & Mediterranean \\
\hline Pseudosasa japonica (Steud.) Makino & Poaceae & Neo & Cas & Bambusoid & Asia \\
\hline $\begin{array}{l}\text { Pseudotsuga menziesii (Mirb.) Franco var. } \\
\text { menziesii }\end{array}$ & Pinaceae & Neo & Cas & Tree & America \\
\hline $\begin{array}{l}\text { Pseudotsuga menziesii (Mirb.) Franco var. glauca } \\
\text { (Beissn.) Franco }\end{array}$ & Pinaceae & Neo & Cas & Tree & America \\
\hline Quercus rubra L. & Fagaceae & Neo & Cas & Tree & America \\
\hline Rhapis excelsa (Thunb.) Henry & Arecaceae & Neo & Nat & Palm & Asia \\
\hline Ricinus communis $\mathrm{L}$. & Euphorbiaceae & Arc & Nat & Shrub & Africa \\
\hline Robinia hispida L. & Fabaceae & Neo & Cas & Tree & America \\
\hline Robinia pseudoacacia $\mathrm{L}$. & Fabaceae & $\mathrm{Neo}$ & Nat & Tree & America \\
\hline Rudbeckia hirta L. & Asteraceae & $\mathrm{Neo}$ & Cas & Herb & America \\
\hline Russelia equisetiformis Schltdl. \& Cham. & Plantaginaceae & Neo & Cas & Shrub & America \\
\hline Salix babylonica L. & Salicaceae & Neo & Nat & Tree & Asia \\
\hline Santolina chamaecyparissus L. & Asteraceae & Arc & Nat & Herb & Mediterranean \\
\hline Saponaria officinalis $\mathrm{L}$. & Caryophyllaceae & Arc & Nat & Herb & Eurasia \\
\hline Schefflera arboricola (Hayata) Merr. & Araliaceae & $\mathrm{Neo}$ & Cas & Shrub & Asia \\
\hline Schinus molle L. & Anacardiaceae & Neo & Cas & Tree & America \\
\hline Schinus terebinthifolius Raddi & Anacardiaceae & $\mathrm{Neo}$ & Cas & Tree & America \\
\hline Scopolia carniolica Jacq. & Solanaceae & Arc & Nat & Herb & Europe \\
\hline Sequoia sempervirens (D.Don) Endl. & Cupressaceae & Neo & Cas & Tree & America \\
\hline Sequoiadendron giganteum (Lindl.) J.Buchholz & Cupressaceae & Neo & Cas & Tree & America \\
\hline Setaria faberi R.A.W.Herrm. & Poaceae & Neo & Nat & Herb & Asia \\
\hline Setaria italica (L.) P.Beauv. & Poaceae & N/A & Nat & Herb & Unknown \\
\hline Setaria viridis (L.) P.Beauv. & Poaceae & Neo & Nat & Herb & Eurasia \\
\hline Sicyos angulatus $\mathrm{L}$. & Cucurbitaceae & $\mathrm{Neo}$ & Nat & Vine & America \\
\hline Sida spinosa $\mathrm{L}$. & Malvaceae & $\mathrm{Neo}$ & Nat & Herb & America \\
\hline Sigesbeckia pubescens (Makino) Makino & Asteraceae & Neo & Cas & Herb & Asia \\
\hline Solanum americanum Mill. & Solanaceae & N/A & Nat & Herb & Unknown \\
\hline
\end{tabular}




\begin{tabular}{|c|c|c|c|c|c|}
\hline Taxa & Family & Res & Stat & \begin{tabular}{|l} 
Simplified \\
growth form
\end{tabular} & Native range \\
\hline Solanum angustifolium Mill. & Solanaceae & $\mathrm{Neo}$ & Cas & Herb & America \\
\hline Solanum elaeagnifolium Cav. & Solanaceae & $\mathrm{Neo}$ & Nat & Herb & America \\
\hline Solanum jasminoides J.Paxton & Solanaceae & $\mathrm{Neo}$ & Cas & Vine & America \\
\hline Solanum luteum Mill. s.l. & Solanaceae & N/A & Nat & Herb & $\begin{array}{l}\text { Mediterranean } \\
\text { \& E Asia }\end{array}$ \\
\hline Solanum lycopersicum L. & Solanaceae & Neo & Cas & Herb & America \\
\hline Solanum pseudocapsicum L. & Solanaceae & Neo & Cas & Herb & America \\
\hline $\begin{array}{l}\text { Solanum pseudocapsicum var. diflorum (Vell.) } \\
\text { Bitter }\end{array}$ & Solanaceae & Neo & Cas & Herb & America \\
\hline Solanum sisymbriifolium Lam. & Solanaceae & $\mathrm{Neo}$ & Nat & Herb & America \\
\hline Solanum sodomaeum $\mathrm{L}$. & Solanaceae & $\mathrm{Neo}$ & Nat & Shrub & Africa \\
\hline Solanum tuberosum L. & Solanaceae & $\mathrm{Neo}$ & Cas & Herb & America \\
\hline Solidago canadensis L. & Asteraceae & Neo & Nat & Herb & America \\
\hline $\begin{array}{l}\text { Sorghum } \times \text { drummondii (Nees ex Steud.) Millsp. } \\
\& \text { Chase }\end{array}$ & Poaceae & $\mathrm{Neo}$ & Cas & Bambusoid & Garden/Hybrid \\
\hline Sorghum bicolor (L.) Moench & Poaceae & Arc & Cas & Bambusoid & Africa \\
\hline Spiraea $\times$ vanhouttei (Briot) Zabel & Rosaceae & $\mathrm{Neo}$ & Cas & Shrub & Garden/Hybrid \\
\hline Sporobolus fertilis (Steud.) Clayton & Poaceae & $\mathrm{Neo}$ & Nat & Herb & Asia \\
\hline Sporobolus indicus (L.) R.Br. & Poaceae & $\mathrm{Neo}$ & Nat & Herb & America \\
\hline Strelitzia reginae Banks & Strelitziaceae & Neo & Cas & Herb & Africa \\
\hline Styphnolobium japonicum (L.) Schott & Fabaceae & Neo & Cas & Tree & Asia \\
\hline Symphyotrichum laeve (L.) Á.Löve \& D.Löve & Asteraceae & Neo & Nat & Herb & America \\
\hline $\begin{array}{l}\text { Symphyotrichum squamatum (Spreng.) } \\
\text { G.L.Nesom }\end{array}$ & Asteraceae & Neo & Nat & Herb & America \\
\hline Syringa vulgaris $\mathrm{L}$. & Oleaceae & $\mathrm{Neo}$ & Nat & Shrub & Europe \\
\hline Tagetes erecta $\mathrm{L}$. & Asteraceae & $\mathrm{Neo}$ & Nat & Herb & America \\
\hline Tagetes minuta $\mathrm{L}$. & Asteraceae & $\mathrm{Neo}$ & Nat & Herb & America \\
\hline Tecoma capensis (Thunb.) Lindl. & Bignoniaceae & Neo & Cas & Vine & Africa \\
\hline Thuja plicata Donn ex D.Don & Cupressaceae & Neo & Nat & Tree & America \\
\hline Tradescantia fluminensis Vell. & Commelinaceae & Neo & Nat & Herb & America \\
\hline Tradescantia pallida (Rose) D.R.Hunt & Commelinaceae & Neo & Cas & Herb & America \\
\hline Tropaeolum majus $\mathrm{L}$. & Tropaeolaceae & $\mathrm{Neo}$ & Nat & Vine & America \\
\hline Ulex europaeus L. & Fabaceae & $\mathrm{Neo}$ & Nat & Shrub & Europe \\
\hline Veronica persica Poir. & Plantaginaceae & $\mathrm{Neo}$ & Nat & Herb & Asia \\
\hline Vinca minor $\mathrm{L}$. & Apocynaceae & Arc & Nat & Herb & Europe \\
\hline Vitis riparia Michx s.l. & Vitaceae & Neo & Cas & Vine & America \\
\hline Washingtonia robusta $\mathrm{H}$.Wendl. & Arecaceae & $\mathrm{Neo}$ & Cas & Palm & America \\
\hline Weigela florida (Bunge) A.DC. & Caprifoliaceae & $\mathrm{Neo}$ & Nat & Shrub & Asia \\
\hline Wisteria sinensis (Sims) Sweet & Fabaceae & $\mathrm{Neo}$ & Nat & Vine & Asia \\
\hline Withania somnifera (L.) Dunal & Solanaceae & Arc & Nat & Shrub & Asia \\
\hline Xanthium spinosum L. & Asteraceae & $\mathrm{Neo}$ & Nat & Herb & America \\
\hline Xanthium strumarium L. s.l. & Asteraceae & Arc & Nat & Herb & America \\
\hline Yucca gloriosa L. & Asparagaceae & Neo & Cas & Succulent & America \\
\hline Zantedeschia aethiopica (L.) Spreng. & Araceae & Neo & Cas & Herb & Africa \\
\hline Zizyphus mauritiana Lamk. & Rhamnaceae & Arc & Nat & Shrub/Tree & Asia \\
\hline
\end{tabular}




\section{Supplementary material I}

Alien flora of Turkey: checklist, taxonomic composition and ecological attributes Authors: Ahmet Uludağ, Necmi Aksoy, Ayşe Yazlık, Zübeyde Filiz Arslan, Efecan Yazmış, İlhan Üremiş, Tiziana Antonella Cossu, Quentin Groom, Jan Pergl, Petr Pyšek, Giuseppe Brundu

Data type: List of alien plants

Explanation note: List of alien taxa in the flora of Turkey. Taxa are ordered alphabetically. Each taxon is listed together with its family, residence time, invasion status, life-form according to Raunkiaer, growth for according to the Thesaurus of Plant Characteristics for Ecology and Evolution, simplified growth-form, life history, reasons for intentional and accidental introduction. The last five columns on the right list habitats where the species is found in Turkey. This list includes also 47 frequently planted taxa.

Copyright notice: This dataset is made available under the Open Database License (http://opendatacommons.org/licenses/odbl/1.0/). The Open Database License $(\mathrm{ODbL})$ is a license agreement intended to allow users to freely share, modify, and use this Dataset while maintaining this same freedom for others, provided that the original source and author(s) are credited. 